\title{
Insight into the mechanisms of action of estrogen receptor $\beta$ in the breast, prostate, colon, and CNS
}

\author{
Prasenjit Dey', Rodrigo P A Barros ${ }^{1}$, Margaret Warner ${ }^{1}$, Anders Ström ${ }^{1}$ and \\ Jan-Åke Gustafsson ${ }^{1,2}$ \\ ${ }^{1}$ Department of Biology and Biochemistry, Center for Nuclear Receptors and Cell Signaling, University of Houston, \\ 3605 Cullen Blvd, Science and Engineering Research Center Bldg 545, Houston, Texas 77204-5056, USA \\ ${ }^{2}$ Department of Biosciences and Nutrition, Karolinska Institutet, Novum, S-141 57 Huddinge, Sweden
}

\author{
Correspondence \\ should be addressed \\ to J-Å Gustafsson \\ Email \\ jgustafsson@uh.edu
}

\begin{abstract}
Estrogen and its receptors (ERs) influence many biological processes in physiology and pathology in men and women. ERs are involved in the etiology and/or progression of cancers of the prostate, breast, uterus, ovary, colon, lung, stomach, and malignancies of the immune system. In estrogen-sensitive malignancies, ER $\beta$ usually is a tumor suppressor and $E R \alpha$ is an oncogene. ER $\beta$ regulates genes in several key pathways including tumor suppression ( $p 53$, PTEN); metabolism (PI3K); survival (Akt); proliferation pathways ( $\mathrm{p} 45^{\mathrm{Skp2}}$, cMyc, and cyclin E); cell-cycle arresting factors (p21 WAF1, cyclin-dependent kinase inhibitor $1(C D K N 1 A)), \mathrm{p} 27^{\mathrm{Kip} 1}$, and cyclin-dependent kinases (CDKs); protection from reactive oxygen species, glutathione peroxidase. Because they are activated by small molecules, ERs are excellent targets for pharmaceuticals. ER $\alpha$ antagonists have been used for many years in the treatment of breast cancer and more recently pharmaceutical companies have produced agonists which are very selective for ER $\alpha$ or ER $\beta$. ER $\beta$ agonists are being considered for preventing progression of cancer, treatment of anxiety and depression, as anti-inflammatory agents and as agents, which prevent or reduce the severity of neurodegenerative diseases.
\end{abstract}
Key Words
- estrogen receptors
- anti-proliferative
- 3ß-Adiol
- cell cycle

\author{
Journal of Molecular \\ Endocrinology \\ (2013) 51, T61-T74
}

\section{Introduction}

In addition to their well-known role in growth and differentiation of the breast, ovary and uterus in females, and testes and prostate in males, estrogen is also required for proper functioning of the cardiovascular, immune, gastrointestinal, musculoskeletal, and nervous systems as well as skin. The most active estrogen in the body is $17 \beta$ estradiol $\left(E_{2}\right)$, which is synthesized in the granulosa cells of the ovary, Leydig cells of the testis (Stocco 2012), adipose tissue (Rice et al. 2012), and brain (Boon et al. 2010).

The classical actions of estrogen are mainly mediated via the two nuclear estrogen receptors (ERs), ER $\alpha$ and ER $\beta$, both of which bind to $\mathrm{E}_{2}$ with high affinity in the low $\mathrm{nM}$ range. Two metabolites of $E_{2}$, estrone $\left(E_{1}\right)$ and estriol $\left(E_{3}\right)$, circulate at high levels at certain phases in the menstrual cycle and during pregnancy (Gruber et al. 2002). $\mathrm{E}_{1}$ and $\mathrm{E}_{3}$ have been thought to be the inactive metabolites of $E_{2}$, but $\mathrm{E}_{3}$ has significant effects on the immune system (Zang et al. 2002, Zhou et al. 2011) and a closer examination of the physiological functions of these two steroids is warranted.

In addition to estrogens, which are synthesized from testosterone and androstenedione through the action of the enzyme aromatase, there is another class of estrogens which do not have an aromatic A-ring. These are 5 -androstene-3 $\beta, 17 \beta$-diol $\left(\mathrm{A}^{5} \mathrm{diol}\right)$, synthesized from 
the adrenal steroid dehydroepiandrosterone, and

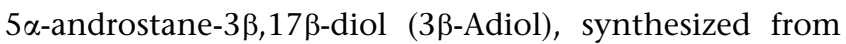
the hormone $5 \alpha$-dihydrotestosterone (DHT). Estrogenic actions of $A^{5}$ diol (Shao et al. 1975) and 3ß-Adiol (Stewart et al. 1977) have been known for many years and their very rapid metabolism in the prostate (Isaacs et al. 1980) and pituitary (Guiraud et al. 1979) was reported. However, it was not until the discovery of ER $\beta$ that the estrogenic actions of these steroids were understood (Weihua et al.

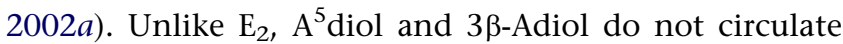
at high concentrations and serve more paracrine and autocrine functions.

$\mathrm{ER} \alpha$ and ER $\beta$ are transcribed from two genes (ESR1 and ESR2 respectively) that are located on different chromosomes (Gosden et al. 1986, Enmark et al. 1997). ER $\alpha$ was discovered more than 50 years ago by Elwood Jensen and the gene was cloned in 1985 (Walter et al. 1985). ER $\beta$ was discovered in 1996 by cross-hybridization of a consensus DNA-binding domain (DBD) probe in a rat prostate cDNA library (Kuiper et al. 1996). ER $\alpha$ protein composed of 595 amino acids (White et al. 1987) is a bit longer than the 530 amino acid-long ER $\beta$. ER $\alpha$ and ER $\beta$ are architecturally similar with six regions (A-F) in the primary amino acid sequence, an arrangement found in all members of the nuclear receptor superfamily (Carson-Jurica et al. 1990). Overall there are three functional domains: N-terminal domain (NTD), DNA binding domain (DBD), and ligandbinding domain (LBD). The two ERs share 97\% similarity in their DBD and 59\% in LBD, whereas the NTD is merely 16\% similar (Fig. 1; Pettersson \& Gustafsson 2001). Although the differences in the LBD are small, they are significant enough to influence the shape of the ligandbinding pocket and that ligands with unique binding affinities for the each receptor have been synthesized (for review see Nilsson et al. (2011)). These ligands are now referred to as specific ER modulators (SERMs). ER $\beta$ binds better than ER $\alpha$ to genistein, a phytoestrogen (Kuiper et al. 1998), which has traditionally been regarded as a healthpromoting and anti-cancer agent. Two years after the discovery of ER $\beta$, another splice variant was discovered and named ER $\beta c x / 2$ (Ogawa et al. 1998). Soon after other splice variants - ER $\beta 4$, and ER $\beta 5$ - were discovered. ER $\beta 4$ were identified from a testis library and ER $\beta 5$ was identified from the MDA-MB-435 cell line (Moore et al. 1998). All the splice variants have a truncated $\mathrm{C}$-terminus with a unique stretch of amino acids fused to the C-terminus. Because of the truncated LBD, these forms have lost their ability to bind estrogens (Leung et al. 2006b) and so far no ligands have been found for these variants.

In addition to the classical ER-binding site on DNA known as the estrogen response element (ERE), ERs can also be recruited to the response elements on DNA without themselves binding to DNA. Instead, they are tethered to other transcription factors (activator protein 1 (AP1), Sp1, and nuclear factor $\kappa \mathrm{B}(\mathrm{NF} \kappa \mathrm{B})$; Webb et al. 1999) and influence the transcription of genes normally regulated by these rather ubiquitous transcription factors. ER $\alpha$ and ER $\beta$ can have opposite effects at these sites: ER $\beta$-tamoxifen acting through AP1 can activate target genes, whereas $\mathrm{ER} \alpha$-tamoxifen may cause repression of the target genes (Webb et al. 2003).

The action of ER $\beta$ at AP1 sites or EREs is determined by the presence of coactivators. In the absence of $E_{2}$, the co-activator Tip60 enhances ER $\beta$ transcriptional activity at AP1 sites, but represses it at EREs. ER $\beta$-selective ligands abolish the repressive actions of ER $\beta$ at ERE, while the

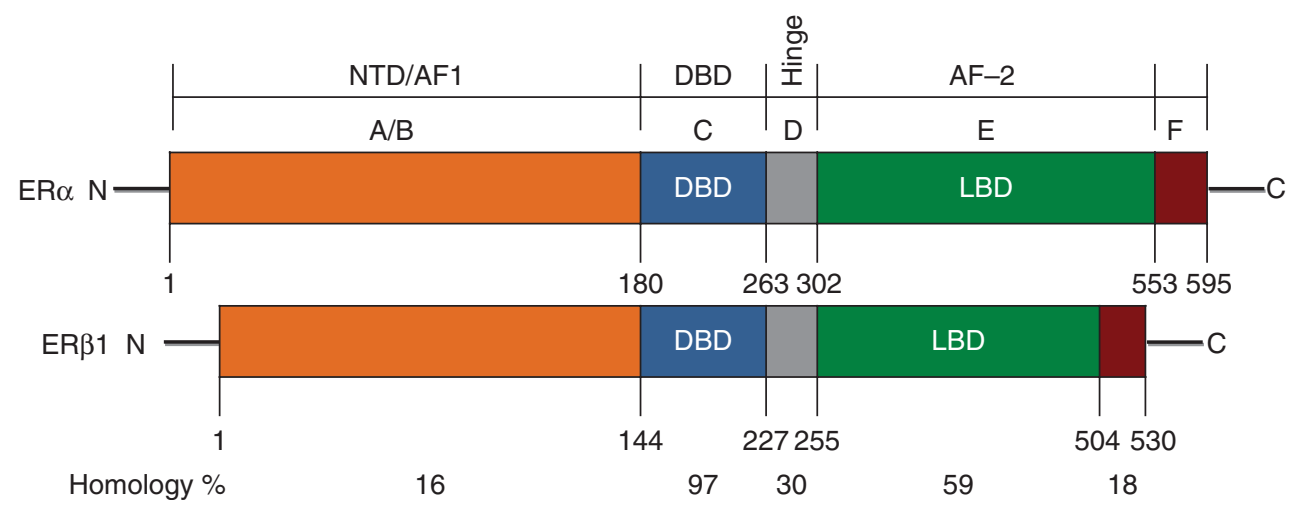

Figure 1

Schematic of the structure of the estrogen receptor (ER). The ER is composed of three main domains: the N-terminal domain (NTD), which contains the activation function 1, the DNA-binding domain (DBD), and the
() 2013 Society for Endocrinology Printed in Great Britain ligand-binding domain (LBD), containing the activation function 2. The DBDs of ER $\alpha$ and ER $\beta$ are highly conserved and the NTDs are the least conserved. The NTD of ER $\alpha$ is shorter than that of ER $\beta$.

Published by Bioscientifica Ltd 
antagonist, ICI 182 780, enhances the transcription at AP1 sites. In addition to being a key player in reparation of double stranded breaks in DNA (Sun et al. 2010), Tip60 is an interesting coactivator in the relationship between ER $\beta$ and AR: TIP60 is an AR coactivator (reviewed in Culig \& Santer (2012) and a facilitator of AR transport into the nucleus (Shiota et al. 2010)). If in the absence of $\mathrm{E}_{2}, \mathrm{ER} \beta$ activation at AP1 sites causes proliferation, then the breasts of postmenopausal women should be proliferating but they are not (Cheng et al. 2013), and ER $\beta$ could increase proliferation in the prostate but it does not (Attia \& Ederveen 2012). Clearly a more detailed analysis of the expression of coactivators in the breast and prostate is needed.

Recent genomic landscaping of ER $\alpha$ and ER $\beta$ binding sites has revealed that while ER $\alpha$ is predominantly found at ERE elements (Carroll et al. 2005), whereas ER $\beta$ is mostly found at AP1 sites (Zhao et al. 2010). This difference in DNA interaction has revealed a very important difference between the two ERs: the DBD is less important for transcriptional activity in ER $\beta$ than it is in ER $\alpha$. The important consequence of this finding is that although removal of one zinc finger of $\mathrm{ER} \alpha$ creates an inactive protein, the same mutation leaves a functional $\operatorname{ER} \beta$ (Price et al. 2001). Thus, it is not surprising that a mouse in which the second zinc finger (ER $\beta$ exon 3 ) was deleted is normal except for the ability to ovulate (Antal et al. 2008).

\section{Mechanisms of ER action}

\section{Ligand-dependent activation of ER}

ERs primarily reside in an inactive state in the cytoplasm in complex with heat-shock protein (Hsp) 50, 70, and 90, which stabilizes the receptor (reviewed in Sanchez (2012)). In the classical model of estrogen action, Hsp dissociates and the DBD of the receptor becomes unveiled when the ligand-binding pocket is occupied. Upon binding to DNA, the receptor causes recruitment of the p160 family of co-regulators such as steroid receptor coactivators (SRCs) or silencing mediator of retinoid and thyroid receptor (SMRT/NCOR2) (Xu et al. 2009). The structure of the ligand that enters the ligand-binding pocket influences the conformation adopted by the receptor and thus either coactivators or corepressors are recruited (Paige et al. 1999, Pike et al. 1999).

\section{Ligand-independent mechanism of action}

ERs can also be activated by ligand-independent mechanisms via cross-talk with other signaling pathways.
Both receptors can be activated via phosphorylation by MAPK and phosphatidylinositide 3-kinase (PI3K; Miller et al. 2011, Riggio et al. 2012, McGlynn et al. 2013). Furthermore, epidermal growth factor receptor (EGFR) and insulin-like growth factor receptor (IGFR), upon activation by their cognate peptide ligands, can activate the serine/threonine kinases, ERK and Akt, which in turn catalyze the phosphorylation and activation of ERs. Posttranscriptional modifications of ERs have been nicely reviewed recently (Le Romancer et al. 2011). Activation of $\mathrm{ER} \alpha$ by kinases is thought to play an important role in breast cancer (reviewed in Thomas \& Gustafsson (2011)).

\section{Physiological and pathophysiological actions of ERs}

The two ERs have distinct functions and act antagonistically in multiple pathways: $\mathrm{ER} \alpha$ plays an important role in growth and proliferation (Maggiolini et al. 2001, Ewan et al. 2005, Sun et al. 2006, Teng et al. 2008) while ER $\beta$ exerts anti-proliferative, differentiative, and apoptotic actions in breast (Lazennec et al. 2001, Paruthiyil et al. 2004, Strom et al. 2004), prostate (Cheng et al. 2004, Pravettoni et al. 2007, McPherson et al. 2010, Dey et al. 2012), and colon cells (Hartman et al. 2009, Bielecki et al. 2011). Both receptors are required for the maintenance of glucose homeostasis with ER $\beta$ predominating in the skeletal muscle and ER $\alpha$ in the adipose tissue (Barros et al. 2009, Barros \& Gustafsson 2011).

\section{Breast and ER}

In the normal mammary gland, ER is essential for branching morphogenesis and in $\mathrm{ER}^{-/-}$mice there is a very rudimentary ductal tree (Couse \& Korach 1999). In the adult gland, in both rodents (Saji et al. 2000) and women (Cheng et al. 2013), ER $\alpha$ is expressed in $<10 \%$ of mammary epithelial cells. ER $\beta$ is expressed in $70-80 \%$ of the mammary epithelial cells and is also expressed in the stroma and immune cells resident in the breast (Clarke et al. 1997, Speirs et al. 2002, Li et al. 2010). ER $\beta^{-/-}$mice revealed that ER $\beta$ is not required for ductal growth of the breast but is required for terminal differentiation and for maintaining the organization and differentiation of epithelial tissue (Forster et al. 2002).

\section{Breast cancer and ER}

According to the statistical evidence (Siegel et al. 2013), one in eight women will develop breast cancer and the

Published by Bioscientifica Ltd 
5-year survival for metastatic breast cancer is $25 \%$. Although initiation and progression of breast cancer involve a complex interplay of many environmental and genetic factors, estrogen plays a very central role (Hankinson et al. 2004). The involvement of estrogen signaling in breast cancer was understood as early as in the 1880s, when surgeons in the USA and Germany were able to treat breast cancer patients by oophorectomy (Love \& Philips 2002). Prolonged exposure to estrogen is a wellestablished risk factor for breast cancer in postmenopausal women (Darbre \& Charles 2010, Fernandez \& Russo 2010). The combination of multiple gene mutations (BRCA1, TP53, and ERBB2) together with the expression of ER $\alpha$ determines the final course and progression of the tumor (Njiaju \& Olopade 2012). About 70\% of breast cancers are ER $\alpha$-positive and respond to anti-estrogen therapies such as tamoxifen, raloxifene, or other SERMs and aromatase inhibitors (Musgrove \& Sutherland 2009). However, onethird of the patients treated with tamoxifen become resistant to treatment. The reason for the development of tamoxifen resistance is not yet clear. Loss of $\mathrm{ER} \alpha$ expression or mutations in $\mathrm{ER} \alpha$ cannot account for all resistance as these occur only in $\sim 15 \%$ of patients (Gutierrez et al. 2005).

The involvement of ER $\beta$ in breast cancer is still being investigated. As reviewed by Murphy \& Leygue (2012), several studies have demonstrated that ER $\beta$ expression in breast cancer, irrespective of presence of $\mathrm{ER} \alpha$, is associated with increased response to endocrine therapy, but others have not found this (Murphy \& Watson 2006). The functions of ER $\beta$ splice variants in breast cancer are another unresolved issue. $\mathrm{ER} \beta 2(\mathrm{ER} \beta \mathrm{cx})$ is a C-terminally spliced form of ER $\beta$ discovered by Ogawa et al. (1998). Some clinical studies have associated the expression of ER $\beta 2$ with poor prognosis and decreased survival of breast cancer patients (Saji et al. 2002); others have found the opposite (Sugiura et al. 2007). Some found that ER $\beta 2$ is not indicative of tamoxifen sensitivity (Esslimani-Sahla et al. 2004) while others have found that it is (Vinayagam et al. 2007). Clearly, more work needs to be done in order to clarify these discrepancies. One suggestion which might be helpful is the use of samples bigger than the traditional biopsy. This is because there is heterogeneity in any breast cancer, with many stages of the disease in each sample and this can only be seen in samples of larger size. Thus some regions of the cancer express ER $\beta$ and some express ER $\beta c x$ and these foci of expression can be missed if small samples are used.

Breast cancer cell lines MCF7, T47D, and MDA231 have been used extensively to study the functions of ER $\alpha$ and ER $\beta$. One of the curious results of these studies is that when ER-negative breast cancer cells, MDA-MB-231, are engineered to express $\mathrm{ER} \alpha$ or $\mathrm{ER} \beta$, both receptors can inhibit proliferation and invasion. The difference is that $\mathrm{ER} \alpha$ requires the presence of ligand for its actions but ER $\beta$ does not (Lazennec et al. 2001). Studies in the T47D breast cancer cell line revealed that in the presence of $E_{2}, E R \alpha$ regulates expression of cell cycle genes such as $c-M Y C$ (MYC), cyclin E, cyclin D, and $\mathrm{p} 45^{\text {Skp2 }}$ (Strom et al. 2004). $\mathrm{ER} \alpha$ interacts with a distal half-ERE and an AP1 site in the enhancer of c-myc and transcriptionally upregulates c-myc expression (Dubik \& Shiu 1992, Wang et al. 2011). Inhibition of $\mathrm{ER} \alpha$ with tamoxifen causes a decrease in cyclin D1 and c-myc expression, which represses downstream targets such as Bcl2 and increases cell death (Butt et al. 2005, Nehra et al. 2010). Very recently, it has been shown that in breast cancer cell lines, ER $\beta$ augmented the antiproliferative effects of tamoxifen (Lattrich et al. 2013).

Many studies show that loss of ER $\beta$ expression occurs frequently in ductal breast, partly because of promoter hypermethylation. Esslimani-Shaha et al. ascribe the progression of the malignancy and tamoxifen resistance to the decreased expression of ER $\beta$ (Shaaban et al. 2003, Esslimani-Sahla et al. 2004, Hopp et al. 2004). However, there are also studies which show high ER $\beta$ expression in ductal cancer and in these studies, ER $\beta$ expression is associated with poor prognosis (Markey et al. 2009, Kim et al. 2012). The reasons for the reported differences in the contribution of ER $\beta$ to breast cancer progression will no doubt be explained as more studies are done and the antibodies used become more standardized.

Despite studies showing beneficial effects of ER $\beta$ in breast cancer, a novel mechanism through which ER $\beta$ might contribute to aggressiveness in Her2-positive breast cancer has been described by Chen et al. According to this study conducted in several breast cancer cell lines, ER $\beta$ expression is associated with high expression of interleukin 8, a cytokine which increases tumor angiogenesis and metastasis (Chen et al. 2011). If it is the relative expression of ERs (ER $\beta 1 / E R \beta 2 / E R \alpha)$ which determines the overall effect of ER $\beta$ in breast cancer, expression of all three receptors and their localization must be measured in order to assess the role of ERs in the prognosis of breast cancer.

\section{Prostate and ER}

$\mathrm{E}_{2}$ via $\mathrm{ER} \alpha$ is required for the development and branching morphogenesis of the prostate (Bosland 2000, Taplin \& Ho 2001, Omoto et al. 2005). However, in the adult mouse prostate there is very little ER $\alpha$ expression and most of it is

Published by Bioscientifica Ltd 
in the stromal compartment. ER $\beta$, on the other hand, is abundantly expressed in the epithelium of the adult mouse and human prostate. It is also expressed in the stroma and the infiltrating immune cells (Schulze \& Barrack 1987, Brenner et al. 1990, Schulze \& Claus 1990, Prins \& Birch 1997, Tsurusaki et al. 2003). The circulating level of $E_{2}$ in males is similar to that in postmenopausal women, i.e. $30 \mathrm{pg} / \mathrm{ml}$ (Taylor et al. 2012). However, in the prostate, the most abundant estrogen is not $\mathrm{E}_{2}$ but 3ß-Adiol (Weihua et al. 2002b).

\section{Prostate cancer and ER}

Studies on ER $\beta^{-1-}$ mice showed prostatic hyperplasia in 5-month-old mice and PIN lesions in mice older than 1 year (Weihua et al. 2002b). This was the first in a series of observations made in mouse models and cancer cell lines, demonstrating an anti-proliferative function of ER $\beta$. In vitro models for studying the role of ER $\beta$ in prostate cancer are very artificial because prostate cancer cell lines do not express or express very low levels of ER $\beta$. It is always questionable as to whether results obtained by overexpression of ER $\beta$ in a cancer cell line can be extrapolated to clinical situations. Nevertheless, interesting information about the antiproliferative effects of ER $\beta$ has been obtained when ER $\beta$ was introduced into prostate cancer cell lines. In 2008, Hurtado et al. (2008) found that overexpression of ER $\beta$ in LNCaP cells caused G1 cell cycle arrest. More recently we found that when ER $\beta$ is expressed in PC 3 and 22RV1 cells, there is a decrease in the expression of proliferative and oncogenic factors ( $\mathrm{p} 45^{\text {Skp2 }}, \mathrm{c}-\mathrm{myc}$, and cyclin E) and an increase in cell-cycle arresting factors (p21 ${ }^{\mathrm{WAF} 1}$, cyclin-dependent kinase inhibitor 1

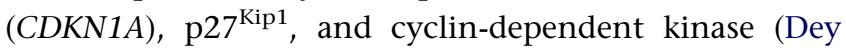
et al. 2012)). Thus ER $\beta$ can inhibit proliferation in both androgen-dependent (LNCaP and 22RV1) and androgenindependent (PC3) prostate cancer cell lines.

In DU145 cells, ER $\beta$ is activated by ICI 182780 , an antiestrogen. Treatment of DU145 cells with ICI 182780 stabilized the tumor suppressor, Krüppel-like zinc finger transcription factor 5 (KLF5), thereby increasing the expression of the antiproliferative transcription factor, forkhead box protein $\mathrm{O} 1$ (FOXO1). The increase in transcription of the FOXO1 gene involves the recruitment of KLF5-ERß-CBP (CREB-binding protein) complex to the promoter of FOXO1. The increase in transcription can be opposed by $\mathrm{E}_{2}$, which promotes proteasome-dependent degradation of KLF5 (Nakajima et al. 2011). This is one possible mechanism through which ER $\beta$ can oppose $\mathrm{E}_{2}$-induced proliferation. Another anti-proliferative route used by ER $\beta$ was shown by Leung et al. (2006a) in DU145 cells. In these cells, ICI 182780 in the presence of ER $\beta$ opposed the action of NFKB which led to decreased cell proliferation. In a recent study we have found that ER $\beta$ promotes apoptosis in prostate by the upregulation of p53-upregulated modulator of apoptosis (PUMA) via transcriptional activation of FOXO3a (Dey et al. 2013).

Results obtained from prostate cancer cell lines point to an important role of ER $\beta$ in repressing key oncogenes (PI3K, p45 ${ }^{\mathrm{Skp} 2}$, c-myc, and cyclin E; Dey et al. 2012) and increasing expression of antiproliferative genes like PTEN (Lindberg et al. 2011), FOXO3, KLF5, p21 WAF1, CDKN1A, and $\mathrm{p} 27^{\mathrm{Kip} 1}$; why has this not translated to a more enthusiastic embrace of ER $\beta$ as a target in prostate cancer by urologists? The problem probably lies in the confusion over the phenotype of ER $\beta^{-1-}$ mice and the questions raised in laboratories where no prostatic phenotype was observed in ER $\beta^{-l-}$ mice (Antal et al. 2008).

As discussed above, exon 3 deletion does not create an $\mathrm{ER} \beta^{-1-}$ mouse, so some of the controversies are related to inappropriate strategy for creating ER $\beta^{-/-}$mice. A key clinical study published in 2008 should have dispelled all doubts about the beneficial role of ER $\beta$ in protecting against prostate cancer. This study showed that expression of the fusion gene TMPRSS2:ERG, which is thought to be responsible for up to $80 \%$ of prostate cancers, is repressed by ER $\beta$. The study was a meta-analysis of biopsy samples collected from 455 prostate cancer patients in the Swedish Watchful Waiting cohort (1987-1999) and the USA-based Physicians Health Study cohort (1983-2003) and the effect of ER $\beta$ was confirmed in NCI-H660 cancer cells, where the inhibition of TMPRSS2:ERG fusion is prevented by ER $\beta$ but not ER $\alpha$ agonists (Setlur et al. 2008). Transmembrane protease, serine 2 (TMPRSS2) is an AR-regulated gene (Paoloni-Giacobino et al. 1997). In certain forms of prostate cancer, there is a chromosomal translocation followed by a gene fusion which results in TMPRSS2 insertion into the promoter region of the erythroblast transformation-specific (ETS) family of transcription factors, ERG and ETV1. Expression of this fusion gene leads to castration resistant prostate cancer (Tomlins et al. 2005, Yu et al. 2010). To date although there are safe and effective ER $\beta$ agonists (Malamas et al. 2004), no ER $\beta$ agonist has been tested in prostate cancer patients. A similar remarkable effect of ER $\beta$ agonists has been observed in the TRAMP mouse (transgenic mouse model for prostate cancer; Gingrich et al. 1996). In this mouse model of prostate cancer, dietary genistein, is an ER $\beta$ dependent pathway, reduced the incidence of prostate

Published by Bioscientifica Ltd 
cancer and the severity of the invasive cancer was increased in ER $\beta^{-1-}$ mice (Slusarz et al. 2012).

One other confounding factor occurring in prostate cancer is the expression of the ER $\beta$ splice variant ER $\beta 2$. As rodents do not express this splice variant, conclusions about its role in prostate cancer have come from its measurement in prostate cancers (Fujimura et al. 2001, Lee et al. 2013) and from overexpression in cell lines (Dey et al. 2012). So far, there is agreement that the expression of ER $\beta 2$ in prostate cancer is associated with a poor prognosis (Leung et al. 2010). The reason for the negative effects of ER $\beta 2$ is not clear but if it has actions, which are opposite to those of ER $\beta$ (Dey et al. 2012), then it might promote survival under the conditions of hypoxia. One of the mechanisms through which ER $\beta$ exerts antiproliferative effects is its facilitation of HIF1 $\alpha$ degradation (Mak et al. 2013). The effects of ER $\beta 2$ on the stability of HIF $1 \alpha$ remain to be determined.

\section{Understanding androgen metabolism in prostate cancer}

As is the case with metabolites of estrogen, metabolites of DHT may play important physiological roles. DHT is more a potent androgen than testosterone, so inhibition of the enzyme which catalyzes the conversion of testosterone to DHT should reduce AR activity. However, the use of $5 \alpha$-reductase inhibitors showed an important negative consequence of inhibition of this enzyme. In the Prostate Cancer Prevention Trial (PCPT), patients treated with the $5 \alpha$-reductase inhibitor, finasteride, showed a decrease of $25 \%$ in prostate cancer prevalence, but a higher rate of Gleason grade (7-10) (37\%) over the placebo-treated group (22.2\%). A possible explanation for this aberration is that the inhibition of synthesis of DHT also results in the loss of the DHT metabolite, 3 3 -Adiol, a prostatic ligand of ER $\beta$ (Imamov et al. 2004, Briganti 2009). More recently, the long-term treatment of prostate cancer with finasteride has revealed that this drug has no effect on prostate

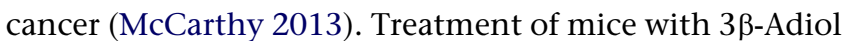
resulted in a decreased cell proliferation in the ventral prostate of wild type but not in ER $\beta$ knockout animals (Weihua et al. 2002a).

\section{Additional beneficial effects of ER $\beta$ in prostate cancer}

In addition to its antiproliferative actions, ER $\beta$ is also antimigratory and is an inhibitor of epithelial to mesenchymal transition (EMT). In one of the first cell-based studies demonstrating an anti-migratory effect of ER $\beta$, adenovirus-mediated delivery of ER $\beta$ led to a strong decrease in the invasiveness of DU145 cells compared with the control transfected cells (Cheng et al. 2004). Metastasis of ER $\beta$-expressing xenografts of DU145 was blocked by treatment with $3 \beta$-Adiol (Guerini et al. 2005). Seven years later, Grubisha et al. (2012) investigated the mechanism through which ER $\beta$, activated by $3 \beta$-Adiol, opposes cell migration and motility of DU145 cells. They found that this anti-migratory effect of ER $\beta$ is opposed by transforming growth factor $\beta$ (TGF $\beta$ ) signal-derived reactive oxygen species (ROS) such as $\mathrm{H}_{2} \mathrm{O}_{2}$. Cyclooxygenase 2 (Cox2) in the stromal cells is responsible for the production of $\mathrm{H}_{2} \mathrm{O}_{2}$, which, in turn, prevents binding of ER $\beta$ to the promoter of E-cadherin. Agents neutralizing $\mathrm{H}_{2} \mathrm{O}_{2}$ and Cox 2 could reverse the inhibition of ER $\beta$ by ROS (Fig. 2; Grubisha et al. 2012).

Mak et al. (2010) showed that ER $\beta$ promotes an epithelial phenotype and opposes EMT in both androgen-dependent and androgen-independent cell lines. The authors suggested that TGF $\beta$ and hypoxia may cause a decrease in ER $\beta$ expression and promote migration and invasion, features of EMT. The paper highlights the point that the Hif1 $\alpha /$ VEGF-A/Snail pathway, required for the genesis of EMT, is opposed by ER $\beta$ (Mak et al. 2010). Reduced EMT and migration occurs in xenographs of PC3 and $22 \mathrm{Rv} 1$ cells when they are induced to overexpress ER $\beta$. We found that ER $\beta$ represses the metastasis factor Runx2, the EMT factor Slug and $\beta$-catenin (Dey et al. 2012). ER $\beta$ is expressed in $\mathrm{BPH}$ and low Gleason grade prostate cancer, but is reduced above Gleason grade 3 (Yang et al. 2007, Mak et al. 2010). However, there is a report that ER $\beta$ expression re-emerges in metastatic prostate cancer (Lai et al. 2004).

\section{Colon}

The Women's Health Initiative Study in 2002 not only showed an increased risk of stroke and heart disease in women on hormone replacement therapy, but it also showed a reduced risk of colon cancer (Rossouw et al. 2002). In agreement with this finding, a study by Cleveland et al. showed that disruption of estrogen signaling increased intestinal neoplasia in Apc $(\mathrm{Min} /+)$ mice. Furthermore, it appears that ER $\beta$ is important for the tumor suppressive effect, while disruption of ER $\alpha$ signaling has no effect (Cleveland et al. 2009). Several other studies support the tumor suppressive effect of ER $\beta$ in colon. One study showed increased induction of mucin-depleted foci in ER $\beta^{-1-}$ mice (Saleiro et al. 2010), while another study showed that ER $\beta^{-1-}$ mice developed more colitisassociated neoplasia (Saleiro et al. 2012). In agreement

Published by Bioscientifica Ltd 


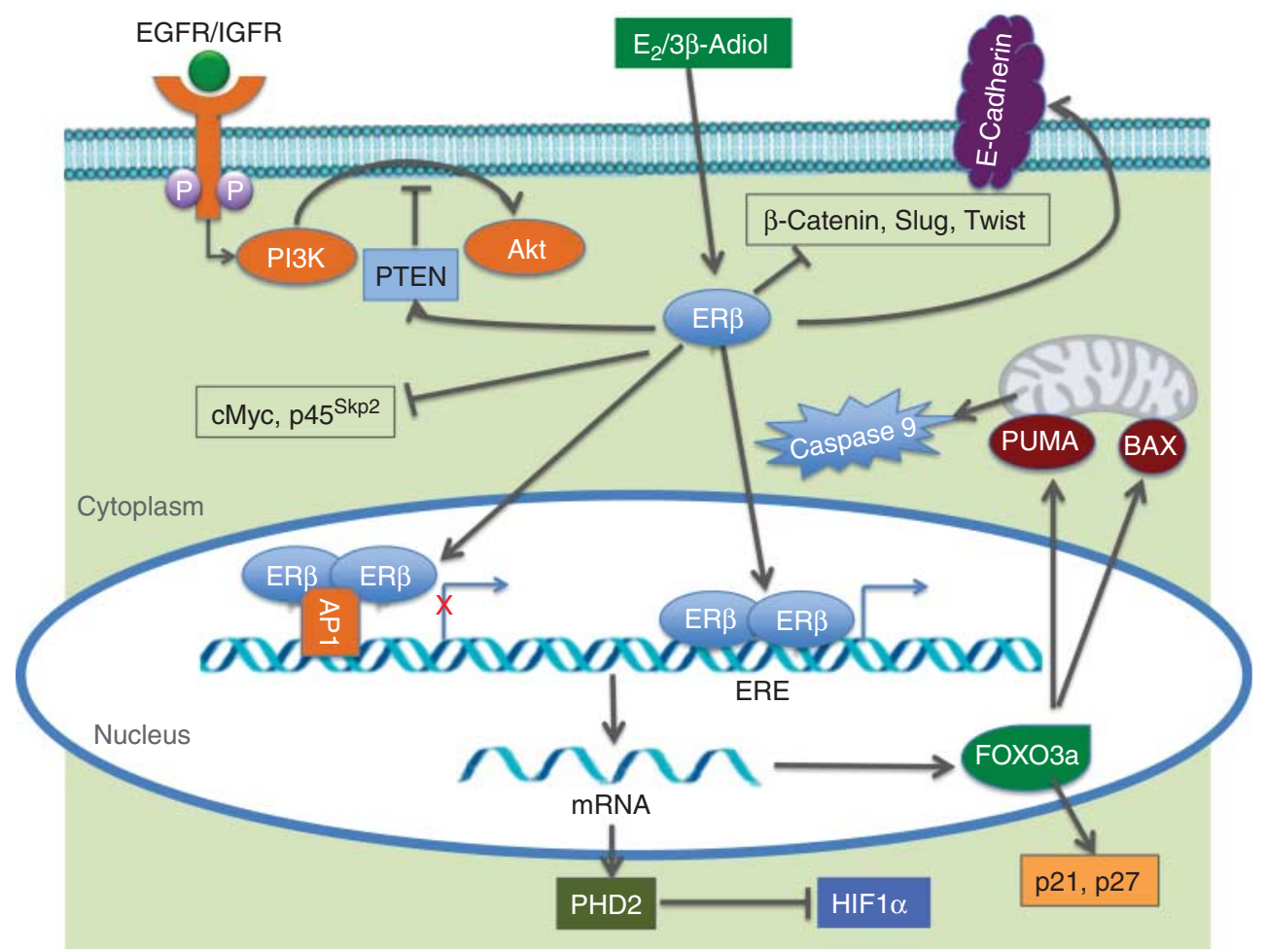

\section{Figure 2}

Pathways regulated by ER $\beta$. ER $\beta$ upon binding to its ligand $3 \beta$-Adiol/ $8 \beta$-VE2/DPN gets activated and transcriptionally upregulates downstream target genes such as FOXO3a and PHD2. The target genes carry ER $\beta$ binding elements such as ERE or AP1-ERE-half-site upstream or downstream of the transcriptional start site. The activated FOXO3a in turn transcriptionally upregulates PUMA, p21, and p27. PHD2 inhibits HIF1 $\alpha$ by prolyl

with this finding ER $\beta$ has been shown to stimulate antiinflammatory networks in colon cancer cell lines (Edvardsson et al. 2011). Expression of ER $\beta$ in colon cancer is correlated to prognosis where a decreased expression is found in higher grade and larger tumors (Konstantinopoulos et al. 2003, Rudolph et al. 2012), and the level is inversely correlated with more advanced Dukes' staging (Jassam et al. 2005). A role of ER $\alpha$ in colon cancer has not been found so far. A hint that it may be involved in progression comes from a study by Armstrong et al. using azoxymethane to induce colon cancer. The study showed that ER $\beta$ expression decreases in colonic epithelial cells as the cancer progresses, while expression of ER $\alpha$ increases, suggesting a possible role of $\mathrm{ER} \alpha$ in colorectal cancer progression (Armstrong et al. 2013). From the phenotype of ER $\beta^{-/-}$mice, ER $\beta$ in the colon appears to decrease proliferation and increase apoptosis, suggesting a tumor suppressive and tumor preventive effect (Wada-Hiraike et al. 2006). ER $\beta$ has also been shown to change the micro RNA pool in human hydroxylation of the oxygen-dependent degradation domain (ODDD), which targets HIF $1 \alpha$ proteins for proteasomal degradation by promoting their interaction with von Hippel-Lindau (VHL). ER $\beta$ also inhibits proliferation of genes such as C-MYC and $\mathrm{p} 45^{\mathrm{skp} 2}$ by an as yet unknown mechanism. Moreover, some of the EMT and bone metastasis genes, such as $\beta$-catenin, SLUG/SNAIL and TWIST, are opposed by ER $\beta$.

colorectal cancer cells (Edvardsson et al. 2013) and to regulate miR-135b and mismatch repair gene expressions in colorectal cells (He et al. 2012).

The incidence of colorectal cancer is much lower in Asian countries than in the Western world, an effect that possibly can be explained by a high dietary intake of phytoestrogens in the form of soy (Lechner et al. 2005). The protective effects of soy are thought to be mediated by binding of genistein, the main phytoestrogen in soy, to ER $\beta$. Genistein binds to ER $\beta$ with 20-fold higher affinity than ER $\alpha$ (Kuiper et al. 1997). Genistein is also a tyrosine kinase inhibitor and some of its actions in the colon may be elicited through its inhibition of tyrosine kinase (Wang et al. 2012). Using the Apc $(\mathrm{Min} /+)$ mouse model of colorectal cancer, Javid et al. (2005) showed that coumestrol, another phytoestrogen with no tyrosine kinase inhibitory activity, as well as $\mathrm{E}_{2}$ inhibit intestinal tumorigenesis in ovariectomized mice. Both clinical studies and animal experiments suggest that phytoestrogens and $\mathrm{E}_{2}$ have a preventive effect on colorectal cancer by acting through ER $\beta$.

Published by Bioscientifica Ltd 
CNS

ER $\beta$ and neuro-protection ERs have been shown to affect the brain in several ways. ER $\alpha$ is responsible for imprinting of the male brain during embryonic development (Naftolin 2008), while ER $\beta$ is involved in cortical layering and migration of interneurons in the fetal period and neonatal period (Wang et al. 2003, Fan et al. 2006).

ER $\beta$ agonists can modulate tryptophan hydroxylase 1 mRNA expression in the raphe nucleus and cause antidepressant-like effects (Clark et al. 2012, Suzuki et al. 2013). The mechanism involves increase of serotonergic activity by regulating synthesis of serotonin. In addition, serotonin receptors are regulated by estrogens in an ER $\beta$-dependent way (Osterlund 2010). Both ER $\alpha$ and ER $\beta$ appear to have protective roles in the brain, where $E_{2}$ attenuates secondary injury via $\mathrm{ER} \alpha$ in the rat brain following subarachnoid hemorrhage (Raval et al. 2013). In the paraventricular nucleus (PVN) and rostroventrolateral medulla, ER $\beta$ protects against aldosterone/ salt-induced hypertension in female rats by inhibiting mineralocorticoid receptor induced increases in ROS (Xue et al. 2013). Ma et al. (2013) have shown that dietary soy and isoflavones by reducing VEGF are neuroprotective in cerebral ischemia. Not much is known about the ER $\beta$ splice variants in the brain with the exception of ER $\beta 5$, which is increased in glioma cells (Li et al. 2013) where its expression is induced by hypoxia and HIF1 $\alpha$. Furthermore, in these cells, ER $\beta 5$ reduced cell proliferation and AKT signaling and increased PTEN expression and may play a role in repression of tumor growth.

ER $\beta$ has profound effects on neuroinflammation and ER $\beta$-selective ligands are very effective in the treatment of neuroinflammation in mouse models (Kumar et al. 2013, $\mathrm{Wu}$ et al. 2013). In addition to multiple sclerosis, neuroinflammation plays a role in the etiology and/or progression also of other CNS diseases. These include Parkinson's disease (Koutsilieri et al. 2013), Alzheimer's disease (Fuster-Matanzo et al. 2013), bipolar disorder (Stertz et al. 2013), and autism (Theoharides et al. 2013). In neurodegenerative diseases, one of the mechanisms of progression and damage to healthy neurons in the vicinity of lesions is overactive microglia. Microglia are the policeman of the brain sensing and kill diseased cells and foreign invaders by secreting powerful cytokines (Benjamins 2013). In this process, neighboring normal cells can be damaged. ER $\beta$ but not $E R \alpha$ is expressed in microglia and ER $\beta$-selective ligands can prevent microglial activation and secretion of cytokines (Wu et al. 2013). The antiinflammatory effects of ER $\beta$ are not confined to microglia.
ER $\beta$ is also expressed in T cells, in particular in Th1 cells, where it regulates indolamine-2,3-dioxygenase (IOD), the rate-limiting step in tryptophan degradation (Harden \& Egilmez 2012). This enzyme causes cell death by depleting tryptophan and by cytotoxicity of the tryptophan metabolite, kynurenine. IOD is an important mediator of immune tolerance via inhibition of Th1 responses and its loss is associated with autoimmune disease (McGaha et al. 2012). The immunosuppressive property of IOD is essential for immune tolerance and in inhibition of Th1 cells that are responsible for experimental autoimmune encephalitis, a mouse model of multiple sclerosis.

ERs and feeding behavior $E_{2}$ has long been recognized as an anorexigenic factor, but the mechanisms behind this effect are still being investigated (Barros \& Gustafsson 2011, Eckel 2011). ER $\alpha$ and/or ER $\beta$ are expressed in the regions of the hypothalamus that regulate feeding and satiety (Roepke 2009; Table 1).

In the arcuate nucleus, ER $\alpha$ is expressed in the pro-opiomelanocortin neurons which secrete two anorexigenic peptides, $\alpha$-melanocyte-stimulating hormone, and cocaine- and amphetamine-regulated

Table 1 Feeding peptides regulated by estrogen receptors (ERs) in the hypothalamus

\begin{tabular}{|c|c|c|c|}
\hline $\begin{array}{l}\text { Nucleus of the } \\
\text { hypothalamus }\end{array}$ & $\begin{array}{l}\text { ER } \\
\text { expressed }\end{array}$ & $\begin{array}{l}\text { Peptide } \\
\text { expressed }\end{array}$ & Function \\
\hline Arcuate nucleus & $\mathrm{ER} \alpha$ & $\begin{array}{l}\text { Cocaine- and } \\
\text { amphetamine- } \\
\text { regulated } \\
\text { transcripts } \\
\alpha \text {-Melanocyte- } \\
\text { stimulating } \\
\text { hormone }\end{array}$ & Anorexigenic \\
\hline Arcuate nucleus & $\mathrm{ER} \alpha$ and $\mathrm{ER} \beta$ & $\begin{array}{l}\text { Neuropeptide } Y \\
\text { Agouti gene- } \\
\text { related protein }\end{array}$ & $\begin{array}{l}\text { Orexigenic } \\
\text { Orexigenic }\end{array}$ \\
\hline \multirow[t]{2}{*}{ Lateral } & None & $\begin{array}{l}\text { Melanin- } \\
\text { concentrating } \\
\text { hormone }(\mathrm{MCH})\end{array}$ & Orexigenic \\
\hline & & Orexin neurons & Orexigenic \\
\hline Dorsomedial & $\mathrm{ER} \alpha$ and $\mathrm{ER} \beta$ & $\begin{array}{l}\text { Neuropeptide } Y \\
\text { Cocaine- and } \\
\text { amphetamine- } \\
\text { regulated } \\
\text { transcripts }\end{array}$ & $\begin{array}{l}\text { Orexigenic } \\
\text { Anorexigenic }\end{array}$ \\
\hline $\begin{array}{l}\text { Paraventricular } \\
\text { nucleus }\end{array}$ & $\mathrm{ER} \beta$ & Urocortin & $\begin{array}{c}\text { Anorexigenic } \\
\text { (repressed } \\
\text { by ER } \beta \text { ) }\end{array}$ \\
\hline \multirow[t]{2}{*}{ Ventromedial } & $\mathrm{ER} \alpha$ & $\begin{array}{l}\text { Brain-derived } \\
\text { neurotrophic } \\
\text { factor }\end{array}$ & Anorexigenic \\
\hline & & Urocortin & Anorexigenic \\
\hline
\end{tabular}

Published by Bioscientifica Ltd 
transcripts (CART). Both ER $\alpha$ and ER $\beta$ are expressed in the neuropeptide Y (NPY) neurons (Roepke 2009, de Souza et al. 2011) which secrete NPY and agouti gene-related protein, two orexigenic peptides (Pillot et al. 2011).

In the lateral hypothalamus, there are two types of orexigenic neurons, the melanin-concentrating hormone neurons and the orexin neurons (Horvath 2006, Nahon 2006). Neither of the ERs have been identified in either of these neurons, and it is thought that the regulation of feeding and satiety by ERs in the lateral hypothalamus is indirect (Muschamp \& Hull 2007). The dorsomedial hypothalamus expresses both ER $\alpha$ and ER $\beta$ and secretes both the orexigenic peptide, NPY, and the anorexigenic peptide CART. In the PVN, which responds to glucose and lipids, ER $\beta$ is abundant and decreases the expression of urocortin, a potent anorexigenic peptide (Haeger et al. 2006). Stimulation of this nucleus increases food intake (Horvath 2006, Roepke 2009). The ventromedial hypothalamus is mainly regulated by ER $\alpha$ and is an important inhibitor of satiety and food intake (Xu et al. 2003). Inhibition of $\mathrm{ER} \alpha$ signaling in this nucleus is associated with hyperphagia, obesity, decreased glucose tolerance, and reduced energy expenditure (Musatov et al. 2007). Brain-derived neurotrophic factor (Gotoh et al. 2013) and urocortin (Chen et al. 2012) are the anorexigenic peptides secreted by neurons of the ventromedial hypothalamus.

Although the precise role of each ER in the regulation of feeding and satiety is still under investigation, it seems that $\mathrm{ER} \alpha$ plays a dominant role in anorexia and ER $\beta$ in the stimulation of feeding.

\section{Conclusions}

This review covers recent advances in estrogen signaling with a focus on ER $\beta$. Since its discovery in 1996, ER $\beta$ has changed our understanding of the mechanisms of estrogen action. It appears that the two ERs often have an antagonistic or yin/yang relationship, e.g. in control of cell proliferation where $\mathrm{ER} \alpha$ is pro-proliferative whereas ER $\beta$ is anti-proliferative. Accordingly, ER $\beta$ is a promising potential target for anti-cancer drugs. Furthermore, ER $\beta$ is an important mediator of estrogen action in the CNS, again offering promise as a drug target in the treatment of, e.g. multiple sclerosis, Parkinson's disease, and eating disorders.

\section{Declaration of interest}

The authors declare that there is no conflict of interest that could be perceived as prejudicing the impartiality of the review reported.

\section{Funding}

This work was supported by The Cancer Prevention and Research Institute of Texas (CPRIT) grant numbers HIRP100680 and RP110444, the Texas Emerging Technology Fund under Agreement no. 300-9-1958, the Robert A Welch Foundation (E-0004), and the Swedish Cancer Fund.

\section{References}

Antal MC, Krust A, Chambon P \& Mark M 2008 Sterility and absence of histopathological defects in nonreproductive organs of a mouse ERß-null mutant. PNAS 105 2433-2438. (doi:10.1073/pnas. 0712029105)

Armstrong CM, Billimek AR, Allred KF, Sturino JM, Weeks BR \& Allred CD 2013 A novel shift in estrogen receptor expression occurs as estradiol suppresses inflammation-associated colon tumor formation. Endocrine-Related Cancer 20 515-525. (doi:10.1530/ERC-12-0308)

Attia DM \& Ederveen AG 2012 Opposing roles of ER $\alpha$ and ER $\beta$ in the genesis and progression of adenocarcinoma in the rat ventral prostate. Prostate 72 1013-1022. (doi:10.1002/pros.21507)

Barros RP \& Gustafsson JA 2011 Estrogen receptors and the metabolic network. Cell Metabolism 14289-299. (doi:10.1016/j.cmet.2011.08.005)

Barros RP, Gabbi C, Morani A, Warner M \& Gustafsson JA 2009 Participation of ER $\alpha$ and ER $\beta$ in glucose homeostasis in skeletal muscle and white adipose tissue. American Journal of Physiology. Endocrinology and Metabolism 297 E124-E133. (doi:10.1152/ajpendo.00189.2009)

Benjamins JA 2013 Direct effects of secretory products of immune cells on neurons and glia. Journal of Neurological Sciences 333 30-36. (doi:10. 1016/j.jns.2013.06.001)

Bielecki A, Roberts J, Mehta R \& Raju J 2011 Estrogen receptor- $\beta$ mediates the inhibition of DLD-1 human colon adenocarcinoma cells by soy isoflavones. Nutrition and Cancer 63 139-150. (doi:10.1080/01635581. 2010.516867)

Boon WC, Chow JD \& Simpson ER 2010 The multiple roles of estrogens and the enzyme aromatase. Progress in Brain Research 181 209-232. (doi:10.1016/S0079-6123(08)81012-6)

Bosland MC 2000 The role of steroid hormones in prostate carcinogenesis. Journal of the National Cancer Institute. Monographs 2000 (27) 39-66. (doi:10.1093/oxfordjournals.jncimonographs.a024244)

Brenner RM, West NB \& McClellan MC 1990 Estrogen and progestin receptors in the reproductive tract of male and female primates. Biology of Reproduction 42 11-19. (doi:10.1095/biolreprod42.1.11)

Briganti A 2009 Oestrogens and prostate cancer: novel concepts about an old issue. European Urology 55 543-545. (doi:10.1016/j.eururo. 2008. 12.004)

Butt AJ, McNeil CM, Musgrove EA \& Sutherland RL 2005 Downstream targets of growth factor and oestrogen signalling and endocrine resistance: the potential roles of c-Myc, cyclin D1 and cyclin E. EndocrineRelated Cancer 12 (Suppl 1) S47-S59. (doi:10.1677/erc.1.00993)

Carroll JS, Liu XS, Brodsky AS, Li W, Meyer CA, Szary AJ, Eeckhoute J, Shao W, Hestermann EV, Geistlinger TR et al. 2005 Chromosome-wide mapping of estrogen receptor binding reveals long-range regulation requiring the forkhead protein FoxA1. Cell 122 33-43. (doi:10.1016/ j.cell.2005.05.008)

Carson-Jurica MA, Schrader WT \& O’Malley BW 1990 Steroid receptor family: structure and functions. Endocrine Reviews 11 201-220. (doi:10.1210/edrv-11-2-201)

Chen Y, Chen L, Li JY, Mukaida N, Wang Q, Yang C, Yin WJ, Zeng XH, Jin W \& Shao ZM 2011 ER $\beta$ and PEA3 co-activate IL-8 expression and promote the invasion of breast cancer cells. Cancer Biology \& Therapy 11 497-511. (doi:10.4161/cbt.11.5.14667)

Chen P, Hover CV, Lindberg D \& Li C 2012 Central urocortin 3 and type 2 corticotropin-releasing factor receptor in the regulation of energy homeostasis: critical involvement of the ventromedial hypothalamus. Frontiers in Endocrinology 3 180. (doi:10.3389/fendo.2012.00180) 
Cheng J, Lee EJ, Madison LD \& Lazennec G 2004 Expression of estrogen receptor $\beta$ in prostate carcinoma cells inhibits invasion and proliferation and triggers apoptosis. FEBS Letters 566 169-172. (doi:10.1016/ j.febslet.2004.04.025)

Cheng G, Butler R, Warner M, Gustafsson JA, Wilczek B \& Landgren BM 2013 Effects of short-term estradiol and norethindrone acetate treatment on the breasts of normal postmenopausal women. Menopause 20 496-503. (doi:10.1097/GME.0b013e318276c4ea)

Clark JA, Alves S, Gundlah C, Rocha B, Birzin ET, Cai SJ, Flick R, Hayes E, Ho K, Warrier S et al. 2012 Selective estrogen receptor- $\beta$ (SERM- $\beta$ ) compounds modulate raphe nuclei tryptophan hydroxylase-1 (TPH-1) mRNA expression and cause antidepressant-like effects in the forced swim test. Neuropharmacology 63 1051-1063. (doi:10.1016/j.neuropharm.2012.07.004)

Clarke RB, Howell A, Potten CS \& Anderson E 1997 Dissociation between steroid receptor expression and cell proliferation in the human breast. Cancer Research $\mathbf{5 7}$ 4987-4991.

Cleveland AG, Oikarinen SI, Bynote KK, Marttinen M, Rafter JJ, Gustafsson JA, Roy SK, Pitot HC, Korach KS, Lubahn DB et al. 2009 Disruption of estrogen receptor signaling enhances intestinal neoplasia in Apc(Min/+) mice. Carcinogenesis 30 1581-1590. (doi:10.1093/ carcin/bgp132)

Couse JF \& Korach KS 1999 Estrogen receptor null mice: what have we learned and where will they lead us? Endocrine Reviews 20 358-417. (doi:10.1210/er.20.3.358)

Culig Z \& Santer FR 2012 Androgen receptor co-activators in the regulation of cellular events in prostate cancer. World Journal of Urology $\mathbf{3 0}$ 297-302. (doi:10.1007/s00345-011-0797-6)

Darbre PD \& Charles AK 2010 Environmental oestrogens and breast cancer: evidence for combined involvement of dietary, household and cosmetic xenoestrogens. Anticancer Research 30 815-827.

Dey P, Jonsson P, Hartman J, Williams C, Strom A \& Gustafsson JA 2012 Estrogen receptors $\beta 1$ and $\beta 2$ have opposing roles in regulating proliferation and bone metastasis genes in the prostate cancer cell line PC3. Molecular Endocrinology 26 1991-2003. (doi:10.1210/me.2012. 1227)

Dey P, Ström A \& Gustafsson J-Å 2013 Estrogen receptor $\beta$ upregulates FOXO3a and causes induction of apoptosis through PUMA in prostate cancer. Oncogene [in press]. (doi:10.1038/onc.2013.384)

Dubik D \& Shiu RP 1992 Mechanism of estrogen activation of c-myc oncogene expression. Oncogene 7 1587-1594.

Eckel LA 2011 The ovarian hormone estradiol plays a crucial role in the control of food intake in females. Physiology \& Behavior 104 517-524. (doi:10.1016/j.physbeh.2011.04.014)

Edvardsson K, Strom A, Jonsson P, Gustafsson JA \& Williams C 2011 Estrogen receptor $\beta$ induces antiinflammatory and antitumorigenic networks in colon cancer cells. Molecular Endocrinology 25 969-979. (doi:10.1210/me.2010-0452)

Edvardsson K, Nguyen-Vu T, Kalasekar SM, Ponten F, Gustafsson JA \& Williams C 2013 Estrogen receptor $\beta$ expression induces changes in the microRNA pool in human colon cancer cells. Carcinogenesis $\mathbf{3 4}$ 1431-1441. (doi:10.1093/carcin/bgt067)

Enmark E, Pelto-Huikko M, Grandien K, Lagercrantz S, Lagercrantz J, Fried G, Nordenskjold M \& Gustafsson JA 1997 Human estrogen receptor $\beta$-gene structure, chromosomal localization, and expression pattern. Journal of Clinical Endocrinology and Metabolism 82 4258-4265. (doi:10.1210/jc.82.12.4258)

Esslimani-Sahla M, Simony-Lafontaine J, Kramar A, Lavaill R, Mollevi C, Warner M, Gustafsson JA \& Rochefort H 2004 Estrogen receptor $\beta$ (ER $\beta$ ) level but not its ER $\beta c x$ variant helps to predict tamoxifen resistance in breast cancer. Clinical Cancer Research 10 5769-5776. (doi:10.1158/ 1078-0432.CCR-04-0389)

Ewan KB, Oketch-Rabah HA, Ravani SA, Shyamala G, Moses HL \& Barcellos-Hoff MH 2005 Proliferation of estrogen receptor- $\alpha$-positive mammary epithelial cells is restrained by transforming growth factor- $\beta 1$ in adult mice. American Journal of Pathology 167 409-417. (doi:10.1016/S0002-9440(10)62985-9)

Fan X, Warner M \& Gustafsson JA 2006 Estrogen receptor $\beta$ expression in the embryonic brain regulates development of calretininimmunoreactive GABAergic interneurons. PNAS 103 19338-19343. (doi:10.1073/pnas.0609663103)

Fernandez SV \& Russo J 2010 Estrogen and xenoestrogens in breast cancer Toxicologic Pathology 38 110-122. (doi:10.1177/0192623309354108)

Forster C, Makela S, Warri A, Kietz S, Becker D, Hultenby K, Warner M \& Gustafsson JA 2002 Involvement of estrogen receptor $\beta$ in terminal differentiation of mammary gland epithelium. PNAS 99 15578-15583. (doi:10.1073/pnas.192561299)

Fujimura T, Takahashi S, Urano T, Ogawa S, Ouchi Y, Kitamura T, Muramatsu M \& Inoue S 2001 Differential expression of estrogen receptor $\beta$ (ER $\beta)$ and its C-terminal truncated splice variant $\mathrm{ER} \beta \mathrm{CX}$ as prognostic predictors in human prostatic cancer. Biochemical and Biophysical Research Communications 289 692-699. (doi:10.1006/bbrc. 2001.6038)

Fuster-Matanzo A, Llorens-Martin M, Hernandez F \& Avila J 2013 Role of neuroinflammation in adult neurogenesis and Alzheimer disease: therapeutic approaches. Mediators of Inflammation 2013260925. (doi:10.1155/2013/260925)

Gingrich JR, Barrios RJ, Morton RA, Boyce BF, DeMayo FJ, Finegold MJ, Angelopoulou R, Rosen JM \& Greenberg NM 1996 Metastatic prostate cancer in a transgenic mouse. Cancer Research 56 4096-4102.

Gosden JR, Middleton PG \& Rout D 1986 Localization of the human oestrogen receptor gene to chromosome $6 \mathrm{q} 24 \rightarrow \mathrm{q} 27$ by in situ hybridization. Cytogenetics and Cell Genetics 43 218-220. (doi:10.1159/ 000132325)

Gotoh K, Masaki T, Chiba S, Ando H, Fujiwara K, Shimasaki T, Mitsutomi K, Katsuragi I, Kakuma T, Sakata T et al. 2013 Brain-derived neurotrophic factor, corticotropin-releasing factor, and hypothalamic neuronal histamine interact to regulate feeding behavior. Journal of Neurochemistry 125 588-598. (doi:10.1111/jnc.12213)

Gruber CJ, Tschugguel W, Schneeberger C \& Huber JC 2002 Production and actions of estrogens. New England Journal of Medicine 346 340-352. (doi:10.1056/NEJMra000471)

Grubisha MJ, Cifuentes ME, Hammes SR \& Defranco DB 2012 A local paracrine and endocrine network involving TGF $\beta$, Cox-2, ROS, and estrogen receptor $\beta$ influences reactive stromal cell regulation of prostate cancer cell motility. Molecular Endocrinology 26 940-954 (doi:10.1210/me.2011-1371)

Guerini V, Sau D, Scaccianoce E, Rusmini P, Ciana P, Maggi A, Martini PG, Katzenellenbogen BS, Martini L, Motta M et al. 2005 The androgen derivative $5 \alpha$-androstane-3 $3,17 \beta$-diol inhibits prostate cancer cell migration through activation of the estrogen receptor $\beta$ subtype. Cancer Research 65 5445-5453. (doi:10.1158/0008-5472.CAN-04-1941)

Guiraud JM, Morfin R, Ducouret B, Samperez S \& Jouan P 1979

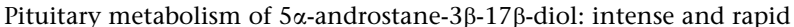
conversion into $5 \alpha$-androstane- $3 \beta, 6 \alpha, 17 \beta$-triol and $5 \alpha$-androstane-

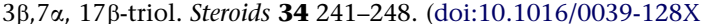
(79) $90076-X)$

Gutierrez MC, Detre S, Johnston S, Mohsin SK, Shou J, Allred DC, Schiff R, Osborne CK \& Dowsett M 2005 Molecular changes in tamoxifenresistant breast cancer: relationship between estrogen receptor, HER-2, and p38 mitogen-activated protein kinase. Journal of Clinical Oncology 23 2469-2476. (doi:10.1200/JCO.2005.01.172)

Haeger P, Andres ME, Forray MI, Daza C, Araneda S \& Gysling K 2006 Estrogen receptors $\alpha$ and $\beta$ differentially regulate the transcriptional activity of the Urocortin gene. Journal of Neuroscience 26 4908-4916. (doi:10.1523/JNEUROSCI.0476-06.2006)

Hankinson SE, Colditz GA \& Willett WC 2004 Towards an integrated model for breast cancer etiology: the lifelong interplay of genes, lifestyle, and hormones. Breast Cancer Research 6 213-218. (doi:10.1186/bcr921) 
Harden JL \& Egilmez NK 2012 Indoleamine 2,3-dioxygenase and dendritic cell tolerogenicity. Immunological Investigations 41 738-764. (doi:10.3109/08820139.2012.676122)

Hartman J, Edvardsson K, Lindberg K, Zhao C, Williams C, Strom A \& Gustafsson JA 2009 Tumor repressive functions of estrogen receptor $\beta$ in SW480 colon cancer cells. Cancer Research 69 6100-6106. (doi:10.1158/0008-5472.CAN-09-0506)

He YQ, Sheng JQ, Ling XL, Fu L, Jin P, Yen L \& Rao J 2012 Estradiol regulates miR-135b and mismatch repair gene expressions via estrogen receptor$\beta$ in colorectal cells. Experimental \& Molecular Medicine 44 723-732. (doi:10.3858/emm.2012.44.12.079)

Hopp TA, Weiss HL, Parra IS, Cui Y, Osborne CK \& Fuqua SA 2004 Low levels of estrogen receptor $\beta$ protein predict resistance to tamoxifen therapy in breast cancer. Clinical Cancer Research 10 7490-7499. (doi:10.1158/1078-0432.CCR-04-1114)

Horvath TL 2006 Synaptic plasticity in energy balance regulation. Obesity 14 (Suppl 5) 228S-233S. (doi:10.1038/oby.2006.314)

Hurtado A, Pinos T, Barbosa-Desongles A, Lopez-Aviles S, Barquinero J, PetrizJ, Santamaria-Martinez A, Morote J, de Torres I, Bellmunt J et al. 2008 Estrogen receptor $\beta$ displays cell cycle-dependent expression and regulates the G1 phase through a non-genomic mechanism in prostate carcinoma cells. Cellular Oncology 30 349-365. (doi:10.3233/CLO-2009-0495)

Imamov O, Lopatkin NA \& Gustafsson JA 2004 Estrogen receptor $\beta$ in prostate cancer. New England Journal of Medicine 351 2773-2774. (doi:10.1056/NEJM200412233512622)

Isaacs JT, McDermott IR \& Coffey DS 1980 The identification and characterization of the $\mathrm{C} 19 \mathrm{O} 3$ steroid metabolites of $5 \alpha$-androstane$3 \beta, 17 \beta$-diol produced by the canine prostate: $5 \alpha$-androstane$3 \beta, 6 \alpha, 17 \beta$-triol and $5 \alpha$-androstane- $3 \beta, 7 \alpha, 17 \beta$-triol. Steroids 35 139-156. (doi:10.1016/0039-128X(80)90099-9)

Jassam N, Bell SM, Speirs V \& Quirke P 2005 Loss of expression of oestrogen receptor $\beta$ in colon cancer and its association with Dukes' staging. Oncology Reports 14 17-21.

Javid SH, Moran AE, Carothers AM, Redston M \& Bertagnolli MM 2005 Modulation of tumor formation and intestinal cell migration by estrogens in the Apc(Min/+) mouse model of colorectal cancer. Carcinogenesis 26 587-595. (doi:10.1093/carcin/bgh346)

Kim TJ, Lee A, Choi YJ, Song BJ, Yim HW \& Kang CS 2012 Prognostic significance of high expression of ER- $\beta$ in surgically treated ER-positive breast cancer following endocrine therapy. Journal of Breast Cancer $\mathbf{1 5}$ 79-86. (doi:10.4048/jbc.2012.15.1.79)

Konstantinopoulos PA, Kominea A, Vandoros G, Sykiotis GP Andricopoulos P, Varakis I, Sotiropoulou-Bonikou G \& Papavassiliou AG 2003 Oestrogen receptor $\beta$ (ER $\beta$ ) is abundantly expressed in normal colonic mucosa, but declines in colon adenocarcinoma paralleling the tumour's dedifferentiation. European Journal of Cancer 39 1251-1258. (doi:10.1016/S0959-8049(03)00239-9)

Koutsilieri E, Lutz MB \& Scheller C 2013 Autoimmunity, dendritic cells and relevance for Parkinson's disease. Journal of Neural Transmission 120 75-81. (doi:10.1007/s00702-012-0842-7)

Kuiper GG, Enmark E, Pelto-Huikko M, Nilsson S \& Gustafsson JA 1996 Cloning of a novel receptor expressed in rat prostate and ovary. PNAS 93 5925-5930. (doi:10.1073/pnas.93.12.5925)

Kuiper GG, Carlsson B, Grandien K, Enmark E, Haggblad J, Nilsson S \& Gustafsson JA 1997 Comparison of the ligand binding specificity and transcript tissue distribution of estrogen receptors $\alpha$ and $\beta$. Endocrinology 138 863-870. (doi:10.1210/en.138.3.863)

Kuiper GG, Lemmen JG, Carlsson B, Corton JC, Safe SH, van der Saag PT, van der Burg B \& Gustafsson JA 1998 Interaction of estrogenic chemicals and phytoestrogens with estrogen receptor $\beta$. Endocrinology 139 4252-4263. (doi:10.1210/en.139.10.4252)

Kumar S, Patel R, Moore S, Crawford DK, Suwanna N, Mangiardi M \& Tiwari-Woodruff SK 2013 Estrogen receptor $\beta$ ligand therapy activates PI3K/Akt/mTOR signaling in oligodendrocytes and promotes remyelination in a mouse model of multiple sclerosis. Neurobiological Disorders 56 131-144. (doi:10.1016/j.nbd.2013.04.005)
Lai JS, Brown LG, True LD, Hawley SJ, Etzioni RB, Higano CS, Ho SM, Vessella RL \& Corey E 2004 Metastases of prostate cancer express estrogen receptor- $\beta$. Urology 64 814-820. (doi:10.1016/j.urology.2004. 05.036)

Lattrich C, Schuler S, Haring J, Skrzypczak M, Ortmann O \& Treeck O 2013 Effects of a combined treatment with tamoxifen and estrogen receptor $\beta$ agonists on human breast cancer cell lines. Archives of Gynecology and Obstetrics [in press]. (doi:10.1007/s00404-013-2977-7)

Lazennec G, Bresson D, Lucas A, Chauveau C \& Vignon F 2001 ER $\beta$ inhibits proliferation and invasion of breast cancer cells. Endocrinology 142 4120-4130. (doi:10.1210/en.142.9.4120)

Lechner D, Kallay E \& Cross HS 2005 Phytoestrogens and colorectal cancer prevention. Vitamins and Hormones 70 169-198.

Lee MT, Ouyang B, Ho SM \& Leung YK 2013 Differential expression of estrogen receptor $\beta$ isoforms in prostate cancer through interplay between transcriptional and translational regulation. Molecular and Cellular Endocrinology 376 125-135. (doi:10.1016/j.mce.2013.06.023)

Le Romancer M, Poulard C, Cohen P, Sentis S, Renoir JM \& Corbo L 2011 Cracking the estrogen receptor's posttranslational code in breast tumors. Endocrine Reviews 32 597-622. (doi:10.1210/er.2010-0016)

Leung YK, Gao Y, Lau KM, Zhang X \& Ho SM $2006 a$ ICI 182,780-regulated gene expression in DU145 prostate cancer cells is mediated by estrogen receptor- $\beta / \mathrm{NF} \kappa \mathrm{B}$ crosstalk. Neoplasia 8 242-249. (doi:10.1593/neo. 05853)

Leung YK, Mak P, Hassan S \& Ho SM $2006 b$ Estrogen receptor (ER)- $\beta$ isoforms: a key to understanding ER- $\beta$ signaling. PNAS 103 13162-13167. (doi:10.1073/pnas.0605676103)

Leung YK, Lam HM, Wu S, Song D, Levin L, Cheng L, Wu CL \& Ho SM 2010 Estrogen receptor $\beta 2$ and $\beta 5$ are associated with poor prognosis in prostate cancer, and promote cancer cell migration and invasion. Endocrine-Related Cancer 17 675-689. (doi:10.1677/ERC-09-0294)

Li S, Han B, Liu G, Li S, Ouellet J, Labrie F \& Pelletier G 2010 Immunocytochemical localization of sex steroid hormone receptors in normal human mammary gland. Journal of Histochemistry and Cytochemistry 58 509-515. (doi:10.1369/jhc.2009.954644)

Li W, Winters A, Poteet E, Ryou MG, Lin S, Hao S, Wu Z, Yuan F, Hatanpaa KJ, Simpkins JW et al. 2013 Involvement of estrogen receptor $\beta 5$ in the progression of glioma. Brain Research 1503 97-107. (doi:10.1016/j.brainres.2013.02.004)

Lindberg K, Helguero LA, Omoto Y, Gustafsson JA \& Haldosen LA 2011 Estrogen receptor $\beta$ represses Akt signaling in breast cancer cells via downregulation of HER2/HER3 and upregulation of PTEN: implications for tamoxifen sensitivity. Breast Cancer Research 13 R43. (doi:10.1186/ bcr2865)

Love RR \& Philips J 2002 Oophorectomy for breast cancer: history revisited. Journal of the National Cancer Institute 94 1433-1434. (doi:10.1093/jnci/ 94.19.1433)

Ma Y, Lovekamp-Swan T, Bekele W, Dohi A \& Schreihofer DA 2013 Hypoxia-inducible factor and vascular endothelial growth factor are targets of dietary soy during acute stroke in female rats. Endocrinology 154 1589-1597. (doi:10.1210/en.2012-2120)

Maggiolini M, Bonofiglio D, Marsico S, Panno ML, Cenni B, Picard D \& Ando S 2001 Estrogen receptor $\alpha$ mediates the proliferative but not the cytotoxic dose-dependent effects of two major phytoestrogens on human breast cancer cells. Molecular Pharmacology 60 595-602.

Mak P, Leav I, Pursell B, Bae D, Yang X, Taglienti CA, Gouvin LM, Sharma VM \& Mercurio AM 2010 ER $\beta$ impedes prostate cancer EMT by destabilizing HIF-1 $\alpha$ and inhibiting VEGF-mediated snail nuclear localization: implications for Gleason grading. Cancer Cell 17 319-332. (doi:10.1016/j.ccr.2010.02.030)

Mak P, Chang C, Pursell B \& Mercurio AM 2013 Estrogen receptor $\beta$ sustains epithelial differentiation by regulating prolyl hydroxylase 2 transcription. PNAS 110 4708-4713. (doi:10.1073/pnas.1221654110)

Malamas MS, Manas ES, McDevitt RE, Gunawan I, Xu ZB, Collini MD, Miller CP, Dinh T, Henderson RA, Keith JC Jr et al. 2004 Design and synthesis of aryl diphenolic azoles as potent and selective estrogen 
receptor- $\beta$ ligands. Journal of Medicinal Chemistry 47 5021-5040. (doi:10.1021/jm049719y)

Markey GC, Cullen R, Diggin P, Hill AD, Mc Dermott EW, O'Higgins NJ \& Duffy MJ 2009 Estrogen receptor- $\beta$ mRNA is associated with adverse outcome in patients with breast cancer. Tumour Biology 30 171-175. (doi:10.1159/000236409)

McCarthy M 2013 Finasteride for prostate cancer prevention has no effect on survival, study finds. BMJ 347 f5203. (doi:10.1136/bmj.f5203)

McGaha TL, Huang L, Lemos H, Metz R, Mautino M, Prendergast GC \& Mellor AL 2012 Amino acid catabolism: a pivotal regulator of innate and adaptive immunity. Immunological Reviews 249 135-157. (doi:10.1111/j.1600-065X.2012.01149.x)

McGlynn LM, Tovey S, Bartlett JM, Doughty J, Cooke TG \& Edwards J 2013 Interactions between MAP kinase and oestrogen receptor in human breast cancer. European Journal of Cancer 49 1176-1186. (doi:10.1016/ j.ejca.2012.11.020)

McPherson SJ, Hussain S, Balanathan P, Hedwards SL, Niranjan B, Grant M, Chandrasiri UP, Toivanen R, Wang Y, Taylor RA et al. 2010 Estrogen receptor- $\beta$ activated apoptosis in benign hyperplasia and cancer of the prostate is androgen independent and TNF $\alpha$ mediated. PNAS 107 3123-3128. (doi:10.1073/pnas.0905524107)

Miller TW, Balko JM, Fox EM, Ghazoui Z, Dunbier A, Anderson H, Dowsett M, Jiang A, Smith RA, Maira SM et al. 2011 ER $\alpha$-dependent E2F transcription can mediate resistance to estrogen deprivation in human breast cancer. Cancer Discovery 1 338-351. (doi:10.1158/2159-8290.CD-11-0101)

Moore JT, McKee DD, Slentz-Kesler K, Moore LB, Jones SA, Horne EL, Su JL, Kliewer SA, Lehmann JM \& Willson TM 1998 Cloning and characterization of human estrogen receptor $\beta$ isoforms. Biochemical and Biophysical Research Communications 247 75-78. (doi:10.1006/bbrc. 1998.8738)

Murphy LC \& Watson PH 2006 Is oestrogen receptor- $\beta$ a predictor of endocrine therapy responsiveness in human breast cancer? Endocrine-Related Cancer 13 327-334. (doi:10.1677/erc.1.01141)

Murphy LC \& Leygue E 2012 The role of estrogen receptor- $\beta$ in breast cancer. Seminars in Reproductive Medicine 30 5-13. (doi:10.1055/s-00311299592)

Musatov S, Chen W, Pfaff DW, Mobbs CV, Yang XJ, Clegg DJ, Kaplitt MG \& Ogawa S 2007 Silencing of estrogen receptor $\alpha$ in the ventromedial nucleus of hypothalamus leads to metabolic syndrome. PNAS $\mathbf{1 0 4}$ 2501-2506. (doi:10.1073/pnas.0610787104)

Muschamp JW \& Hull EM 2007 Melanin concentrating hormone and estrogen receptor- $\alpha$ are coexstensive but not coexpressed in cells of male rat hypothalamus. Neuroscience Letters 427 123-126. (doi:10.1016/ j.neulet.2007.09.031)

Musgrove EA \& Sutherland RL 2009 Biological determinants of endocrine resistance in breast cancer. Nature Reviews. Cancer 9 631-643. (doi:10.1038/nrc2713)

Naftolin F 2008 Sex steroids and the brain. Gynecological Endocrinology 24 533-534. (doi:10.1080/09513590802296104)

Nahon JL 2006 The melanocortins and melanin-concentrating hormone in the central regulation of feeding behavior and energy homeostasis. Comptes Rendus Biologies 329 623-638 (discussion 653-655). (doi:10.1016/j.crvi.2006.03.021)

Nakajima Y, Akaogi K, Suzuki T, Osakabe A, Yamaguchi C, Sunahara N, Ishida J, Kako K, Ogawa S, Fujimura T et al. 2011 Estrogen regulates tumor growth through a nonclassical pathway that includes the transcription factors ER $\beta$ and KLF5. Science Signaling 4 ra22. (doi:10.1126/scisignal.2001551)

Nehra R, Riggins RB, Shajahan AN, Zwart A, Crawford AC \& Clarke R 2010 BCL2 and CASP8 regulation by NF- $\kappa$ B differentially affect mitochondrial function and cell fate in antiestrogen-sensitive and -resistant breast cancer cells. FASEB Journal 24 2040-2055. (doi:10.1096/fj.09-138305)

Nilsson S, Koehler KF \& Gustafsson JA 2011 Development of subtypeselective oestrogen receptor-based therapeutics. Nature Reviews. Drug Discovery 10 778-792. (doi:10.1038/nrd3551)
Njiaju UO \& Olopade OI 2012 Genetic determinants of breast cancer risk: a review of current literature and issues pertaining to clinical application. Breast Journal 18 436-442. (doi:10.1111/j.1524-4741.2012.01274.x)

Ogawa S, Inoue S, Watanabe T, Orimo A, Hosoi T, Ouchi Y \& Muramatsu M 1998 Molecular cloning and characterization of human estrogen receptor $\beta c x$ : a potential inhibitor of estrogen action in human. Nucleic Acids Research 26 3505-3512. (doi:10.1093/nar/26.15.3505)

Omoto Y, Imamov O, Warner M \& Gustafsson JA 2005 Estrogen receptor $\alpha$ and imprinting of the neonatal mouse ventral prostate by estrogen. PNAS 102 1484-1489. (doi:10.1073/pnas.0409168102)

Osterlund MK 2010 Underlying mechanisms mediating the antidepressant effects of estrogens. Biochimica et Biophysica Acta 1800 1136-1144. (doi:10.1016/j.bbagen.2009.11.001)

Paige LA, Christensen DJ, Gron H, Norris JD, Gottlin EB, Padilla KM Chang CY, Ballas LM, Hamilton PT, McDonnell DP et al. 1999 Estrogen receptor (ER) modulators each induce distinct conformational changes in ER $\alpha$ and ER $\beta$. PNAS 96 3999-4004. (doi:10.1073/pnas.96.7.3999)

Paoloni-Giacobino A, Chen H, Peitsch MC, Rossier C \& Antonarakis SE 1997 Cloning of the TMPRSS2 gene, which encodes a novel serine protease with transmembrane, LDLRA, and SRCR domains and maps to 21q22.3. Genomics 44 309-320. (doi:10.1006/geno.1997.4845)

Paruthiyil S, Parmar H, Kerekatte V, Cunha GR, Firestone GL \& Leitman DC 2004 Estrogen receptor $\beta$ inhibits human breast cancer cell proliferation and tumor formation by causing a G2 cell cycle arrest. Cancer Research 64 423-428. (doi:10.1158/0008-5472.CAN-03-2446)

Pettersson K \& Gustafsson JA 2001 Role of estrogen receptor $\beta$ in estrogen action. Annual Review of Physiology 63 165-192. (doi:10.1146/annurev. physiol.63.1.165)

Pike AC, Brzozowski AM, Hubbard RE, Bonn T, Thorsell AG, Engstrom O, Ljunggren J, Gustafsson JA \& Carlquist M 1999 Structure of the ligand-binding domain of oestrogen receptor $\beta$ in the presence of a partial agonist and a full antagonist. EMBO Journal 18 4608-4618. (doi:10.1093/emboj/18.17.4608)

Pillot B, Duraffourd C, Begeot M, Joly A, Luquet S, Houberdon I, Naville D, Vigier M, Gautier-Stein A, Magnan C et al. 2011 Role of hypothalamic melanocortin system in adaptation of food intake to food protein increase in mice. PLOS ONE 6 e19107. (doi:10.1371/journal.pone. 0019107)

Pravettoni A, Mornati O, Martini PG, Marino M, Colciago A, Celotti F, Motta M \& Negri-Cesi P 2007 Estrogen receptor $\beta$ (ER $\beta$ ) and inhibition of prostate cancer cell proliferation: studies on the possible mechanism of action in DU145 cells. Molecular and Cellular Endocrinology 263 46-54. (doi:10.1016/j.mce.2006.08.008)

Price RH Jr, Butler CA, Webb P, Uht R, Kushner P \& Handa RJ 2001 A splice variant of estrogen receptor $\beta$ missing exon 3 displays altered subnuclear localization and capacity for transcriptional activation. Endocrinology 142 2039-2049. (doi:10.1210/en.142.5.2039)

Prins GS \& Birch L 1997 Neonatal estrogen exposure up-regulates estrogen receptor expression in the developing and adult rat prostate lobes. Endocrinology 138 1801-1809. (doi:10.1210/en.138.5.1801)

Raval AP, Borges-Garcia R, Javier Moreno W, Perez-Pinzon MA \& Bramlett H 2013 Periodic $17 \beta$-estradiol pretreatment protects rat brain from cerebral ischemic damage via estrogen receptor- $\beta$. PLOS ONE 8 e60716. (doi:10.1371/journal.pone.0060716)

Rice S, Patel B, Bano G, Ugwumadu A \& Whitehead SA 2012 Aromatase expression in abdominal omental/visceral and subcutaneous fat depots: a comparison of pregnant and obese women. Fertility and Sterility 97 1460-1466 (e1461). (doi:10.1016/j.fertnstert.2012.03.008)

Riggio M, Polo ML, Blaustein M, Colman-Lerner A, Luthy I, Lanari C \& Novaro V 2012 PI3K/AKT pathway regulates phosphorylation of steroid receptors, hormone independence and tumor differentiation in breast cancer. Carcinogenesis 33 509-518. (doi:10.1093/carcin/ bgr303)

Roepke TA 2009 Oestrogen modulates hypothalamic control of energy homeostasis through multiple mechanisms. Journal of Neuroendocrinology 21 141-150. (doi:10.1111/j.1365-2826.2008.01814.x) 
Rossouw JE, Anderson GL, Prentice RL, LaCroix AZ, Kooperberg C, Stefanick ML, Jackson RD, Beresford SA, Howard BV, Johnson KC et al. 2002 Risks and benefits of estrogen plus progestin in healthy postmenopausal women: principal results From the Women's Health Initiative randomized controlled trial. Journal of the American Medical Association 288 321-333. (doi:10.1001/jama.288.3.321)

Rudolph A, Toth C, Hoffmeister M, Roth W, Herpel E, Jansen L, Marx A, Brenner H \& Chang-Claude J 2012 Expression of oestrogen receptor $\beta$ and prognosis of colorectal cancer. British Journal of Cancer $\mathbf{1 0 7}$ 831-839. (doi:10.1038/bjc.2012.323)

Saji S, Jensen EV, Nilsson S, Rylander T, Warner M \& Gustafsson JA 2000 Estrogen receptors $\alpha$ and $\beta$ in the rodent mammary gland. PNAS 97 337-342. (doi:10.1073/pnas.97.1.337)

Saji S, Omoto Y, Shimizu C, Warner M, Hayashi Y, Horiguchi S, Watanabe T, Hayashi S, Gustafsson JA \& Toi M 2002 Expression of estrogen receptor $(\mathrm{ER})(\beta) \mathrm{cx}$ protein in $\mathrm{ER}(\alpha)$-positive breast cancer: specific correlation with progesterone receptor. Cancer Research 62 4849-4853.

Saleiro D, Murillo G, Lubahn DB, Kopelovich L, Korach KS \& Mehta RG 2010 Enhanced induction of mucin-depleted foci in estrogen receptor $\{\beta\}$ knockout mice. Cancer Prevention Research 3 1198-1204. (doi:10.1158/1940-6207.CAPR-10-0044)

Saleiro D, Murillo G, Benya RV, Bissonnette M, Hart J \& Mehta RG 2012 Estrogen receptor- $\beta$ protects against colitis-associated neoplasia in mice. International Journal of Cancer 131 2553-2561. (doi:10.1002/ijc. 27578)

Sanchez ER 2012 Chaperoning steroidal physiology: lessons from mouse genetic models of Hsp90 and its cochaperones. Biochimica et Biophysica Acta 1823 722-729. (doi:10.1016/j.bbamcr.2011.11.006)

Schulze H \& Barrack ER 1987 Immunocytochemical localization of estrogen receptors in the normal male and female canine urinary tract and prostate. Endocrinology 121 1773-1783. (doi:10.1210/endo-121-51773)

Schulze H \& Claus S 1990 Histological localization of estrogen receptors in normal and diseased human prostates by immunocytochemistry. Prostate 16 331-343. (doi:10.1002/pros.2990160408)

Setlur SR, Mertz KD, Hoshida Y, Demichelis F, Lupien M, Perner S, Sboner A, Pawitan Y, Andren O, Johnson LA et al. 2008 Estrogen-dependent signaling in a molecularly distinct subclass of aggressive prostate cancer. Journal of the National Cancer Institute 100 815-825. (doi:10.1093/jnci/djn150)

Shaaban AM, O’Neill PA, Davies MP, Sibson R, West CR, Smith PH \& Foster CS 2003 Declining estrogen receptor- $\beta$ expression defines malignant progression of human breast neoplasia. American Journal of Surgical Pathology 27 1502-1512. (doi:10.1097/00000478-200312000-00002)

Shao TC, Castaneda E, Rosenfield RL \& Liao S 1975 Selective retention and formation of a $\Delta 5$-androstenediol-receptor complex in cell nuclei of the rat vagina. Journal of Biological Chemistry 250 3095-3100.

Shiota M, Yokomizo A, Masubuchi D, Tada Y, Inokuchi J, Eto M, Uchiumi T, Fujimoto N \& Naito S 2010 Tip60 promotes prostate cancer cell proliferation by translocation of androgen receptor into the nucleus. Prostate 70 540-554. (doi:10.1002/pros.21088)

Siegel R, Naishadham D \& Jemal A 2013 Cancer statistics, 2013. CA: A Cancer Journal for Clinicians 63 11-30. (doi:10.3322/caac. 21166)

Slusarz A, Jackson GA, Day JK, Shenouda NS, Bogener JL, Browning JD, Fritsche KL, MacDonald RS, Besch-Williford CL \& Lubahn DB 2012 Aggressive prostate cancer is prevented in $\mathrm{ER} \alpha \mathrm{KO}$ mice and stimulated in ERßKO TRAMP mice. Endocrinology 153 4160-4170. (doi:10.1210/en. 2012-1030)

de Souza FS, Nasif S, Lopez-Leal R, Levi DH, Low MJ \& Rubinsten M 2011 The estrogen receptor $\alpha$ colocalizes with proopiomelanocortin in hypothalamic neurons and binds to a conserved motif present in the neuron-specific enhancer nPE2. European Journal of Pharmacology 660 181-187. (doi:10.1016/j.ejphar.2010.10.114)

Speirs V, Skliris GP, Burdall SE \& Carder PJ 2002 Distinct expression patterns of ER $\alpha$ and ER $\beta$ in normal human mammary gland. Journal of Clinical Pathology 55 371-374. (doi:10.1136/jcp.55.5.371)
Stertz L, Magalhaes PV \& Kapczinski F 2013 Is bipolar disorder an inflammatory condition? The relevance of microglial activation Current Opinion in Psychiatry 26 19-26. (doi:10.1097/YCO.0b013e32835aa4b4)

Stewart ME, Pochi PE, Strauss JS, Wotiz HH \& Clark SJ 1977 In-vitro metabolism of $[3 \mathrm{H}]$ testosterone by scalp and back skin: conversion of testosterone into $5 \alpha$-androstane- $3 \beta, 17 \beta$-diol. Journal of Endocrinology 72 385-390. (doi:10.1677/joe.0.0720385)

Stocco C 2012 Tissue physiology and pathology of aromatase. Steroids $\mathbf{7 7}$ 27-35. (doi:10.1016/j.steroids.2011.10.013)

Strom A, Hartman J, Foster JS, Kietz S, Wimalasena J \& Gustafsson JA 2004 Estrogen receptor $\beta$ inhibits $17 \beta$-estradiol-stimulated proliferation of the breast cancer cell line T47D. PNAS 101 1566-1571. (doi:10.1073/ pnas.0308319100)

Sugiura H, Toyama T, Hara Y, Zhang Z, Kobayashi S, Fujii Y, Iwase H \& Yamashita H 2007 Expression of estrogen receptor $\beta$ wild-type and its variant $\mathrm{ER} \beta \mathrm{cx} / \beta 2$ is correlated with better prognosis in breast cancer. Japanese Journal of Clinical Oncology 37 820-828. (doi:10.1093/jjco/ hym114)

Sun PM, Gao M, Wei LH, Mustea A, Wang JL, Konsgen D, Lichtenegger W \& Sehouli J 2006 An estrogen receptor $\alpha$-dependent regulation of estrogen receptor-related receptor $\alpha$ in the proliferation of endometrial carcinoma cells. International Journal of Gynecological Cancer 16 (Suppl 2) 564-568. (doi:10.1111/j.1525-1438.2006.00697.x)

Sun Y, Jiang X \& Price BD 2010 Tip60: connecting chromatin to DNA damage signaling. Cell Cycle 9 930-936. (doi:10.4161/cc.9.5.10931)

Suzuki H, Barros RP, Sugiyama N, Krishnan V, Yaden BC, Kim HJ, Warner M \& Gustafsson JA 2013 Involvement of estrogen receptor $\beta$ in maintenance of serotonergic neurons of the dorsal raphe. Molecular Psychiatry 18 674-680. (doi:10.1038/mp.2012.62)

Taplin ME \& Ho SM 2001 Clinical review 134: The endocrinology of prostate cancer. Journal of Clinical Endocrinology and Metabolism 86 3467-3477. (doi:10.1210/jc.86.8.3467)

Taylor JA, Richter CA, Suzuki A, Watanabe H, Iguchi T, Coser KR, Shioda T \& vom Saal FS 2012 Dose-related estrogen effects on gene expression in fetal mouse prostate mesenchymal cells. PLOS ONE 7 e48311. (doi:10. 1371/journal.pone.0048311)

Teng J, Wang ZY, Jarrard DF \& Bjorling DE 2008 Roles of estrogen receptor $\alpha$ and $\beta$ in modulating urothelial cell proliferation. Endocrine-Related Cancer 15 351-364. (doi:10.1677/erc.1.01255)

Theoharides TC, Asadi S \& Patel AB 2013 Focal brain inflammation and autism. Journal of Neuroinflammation 10 46. (doi:10.1186/1742-209410-46)

Thomas C \& Gustafsson JA 2011 The different roles of ER subtypes in cancer biology and therapy. Nature Reviews. Cancer 11 597-608. (doi:10.1038/ nrc3093)

Tomlins SA, Rhodes DR, Perner S, Dhanasekaran SM, Mehra R, Sun XW, Varambally S, Cao X, Tchinda J, Kuefer R et al. 2005 Recurrent fusion of TMPRSS2 and ETS transcription factor genes in prostate cancer. Science 310 644-648. (doi:10.1126/science.1117679)

Tsurusaki T, Aoki D, Kanetake H, Inoue S, Muramatsu M, Hishikawa Y \& Koji T 2003 Zone-dependent expression of estrogen receptors $\alpha$ and $\beta$ in human benign prostatic hyperplasia. Journal of Clinical Endocrinology and Metabolism 88 1333-1340. (doi:10.1210/jc.2002-021015)

Vinayagam R, Sibson DR, Holcombe C, Aachi V \& Davies MP 2007 Association of oestrogen receptor $\beta 2$ (ER $\beta 2 / E R \beta c x)$ with outcome of adjuvant endocrine treatment for primary breast cancer - a retrospective study. BMC Cancer 7 131. (doi:10.1186/1471-2407-7-131)

Wada-Hiraike O, Imamov O, Hiraike H, Hultenby K, Schwend T, Omoto Y, Warner M \& Gustafsson JA 2006 Role of estrogen receptor $\beta$ in colonic epithelium. PNAS 103 2959-2964. (doi:10.1073/pnas.0511271103)

Walter P, Green S, Greene G, Krust A, Bornert JM, Jeltsch JM, Staub A, Jensen E, Scrace G, Waterfield M et al. 1985 Cloning of the human estrogen receptor cDNA. PNAS 82 7889-7893. (doi:10.1073/pnas.82. 23.7889)

Wang L, Andersson S, Warner M \& Gustafsson JA 2003 Estrogen receptor (ER) $\beta$ knockout mice reveal a role for ER $\beta$ in migration of cortical 
neurons in the developing brain. PNAS 100 703-708. (doi:10.1073/ pnas.242735799)

Wang C, Mayer JA, Mazumdar A, Fertuck K, Kim H, Brown M \& Brown PH 2011 Estrogen induces c-myc gene expression via an upstream enhancer activated by the estrogen receptor and the AP-1 transcription factor. Molecular Endocrinology 25 1527-1538. (doi:10.1210/me.2011-1037)

Wang H, Li Q \& Chen H 2012 Genistein affects histone modifications on Dickkopf-related protein 1 (DKK1) gene in SW480 human colon cancer cell line. PLoS ONE 7 e40955. (doi:10.1371/journal.pone.0040955)

Webb P, Nguyen P, Valentine C, Lopez GN, Kwok GR, McInerney E, Katzenellenbogen BS, Enmark E, Gustafsson JA, Nilsson S et al. 1999 The estrogen receptor enhances AP-1 activity by two distinct mechanisms with different requirements for receptor transactivation functions. Molecular Endocrinology 13 1672-1685. (doi:10.1210/me.13. 10.1672)

Webb P, Valentine C, Nguyen P, Price RH Jr, Marimuthu A, West BL Baxter JD \& Kushner PJ 2003 ER $\beta$ binds N-CoR in the presence of estrogens via an LXXLL-like motif in the N-CoR C-terminus. Nuclear Receptor 1 4. (doi:10.1186/1478-1336-1-4)

Weihua Z, Lathe R, Warner M \& Gustafsson JA 2002a An endocrine pathway in the prostate, ER $\beta, A R, 5 \alpha$-androstane- $3 \beta, 17 \beta$-diol, and CYP7B1, regulates prostate growth. PNAS 99 13589-13594. (doi:10.1073/pnas.162477299)

Weihua Z, Warner M \& Gustafsson JA $2002 b$ Estrogen receptor $\beta$ in the prostate. Molecular and Cellular Endocrinology 193 1-5. (doi:10.1016/ S0303-7207(02)00089-8)

White R, Lees JA, Needham M, Ham J \& Parker M 1987 Structural organization and expression of the mouse estrogen receptor. Molecular Endocrinology 1 735-744. (doi:10.1210/mend-1-10-735)

Wu WF, Tan XJ, Dai YB, Krishnan V, Warner M \& Gustafsson JA 2013 Targeting estrogen receptor $\beta$ in microglia and T cells to treat experimental autoimmune encephalomyelitis. PNAS 110 3543-3548. (doi:10.1073/pnas.1300313110)
Xu B, Goulding EH, Zang K, Cepoi D, Cone RD, Jones KR, Tecott LH \& Reichardt LF 2003 Brain-derived neurotrophic factor regulates energy balance downstream of melanocortin-4 receptor. Nature Neuroscience 6 736-742. (doi:10.1038/nn1073)

Xu J, Wu RC \& O'Malley BW 2009 Normal and cancer-related functions of the p160 steroid receptor co-activator (SRC) family. Nature Reviews. Cancer 9 615-630. (doi:10.1038/nrc2695)

Xue B, Zhang Z, Beltz TG, Johnson RF, Guo F, Hay M \& Johnson AK 2013 Estrogen receptor- $\beta$ in the paraventricular nucleus and rostroventrolateral medulla plays an essential protective role in aldosterone/saltinduced hypertension in female rats. Hypertension 61 1255-1262. (doi:10.1161/HYPERTENSIONAHA.111.00903)

Yang GS, Wang Y, Wang P \& Chen ZD 2007 Expression of oestrogen receptor- $\alpha$ and oestrogen receptor- $\beta$ in prostate cancer. Chinese Medical Journal 120 1611-1615.

Yu M, Yu J, Mani RS, Cao Q, Brenner CJ, Cao X, Wang X, Wu L, Li J, Hu M et al. 2010 An integrated network of androgen receptor, polycomb, and TMPRSS2-ERG gene fusions in prostate cancer progression. Cancer Cell 17 443-454. (doi:10.1016/j.ccr.2010.03.018)

Zang YC, Halder JB, Hong J, Rivera VM \& Zhang JZ 2002 Regulatory effects of estriol on T cell migration and cytokine profile: inhibition of transcription factor NF-кB. Journal of Neuroimmunology 124 106-114. (doi:10.1016/S0165-5728(02)00016-4)

Zhao C, Gao H, Liu Y, Papoutsi Z, Jaffrey S, Gustafsson JA \& DahlmanWright K 2010 Genome-wide mapping of estrogen receptor- $\beta$-binding regions reveals extensive cross-talk with transcription factor activator protein-1. Cancer Research 70 5174-5183. (doi:10.1158/0008-5472. CAN-09-4407)

Zhou R, Lai Y, Yamabe N, Fukui M \& Zhu BT 2011 Estriol has different effects from $17 \beta$-estradiol in modulating mouse splenocyte function under inflammatory conditions. Journal of Immunotoxicology 8 346-358. (doi:10.3109/1547691X.2011.617791)

Received in final form 4 September 2013

Accepted 9 September 2013

Accepted Preprint published online 12 September 2013
() 2013 Society for Endocrinology Printed in Great Britain
Published by Bioscientifica Ltd 